Chirurgia (2018) 113: 253-260

No. 2, March - April

Copyright@ Celsius

http://dx.doi.org/10.21614/chirurgia.113.2.253

\title{
Prognostic Factors of Treatment Failure for Early Breast Cancer after Breast Conserving Surgery
}

\author{
Mohammad Aldaqaf', Eugen Bratucu² \\ 'Faculty of Medicine and Health Science "Taiz University", Taiz, Yemen \\ 2"Carol Davila" University of Medicine and Pharmacy, Bucharest, Romania
}

Corresponding author: Mohammad Aldaqaf, MD Faculty of Medicine and Health Science "Taiz University" Taiz, Yemen

E-mail: aldakafm@yahoo.com

\author{
Abbreviations: \\ ALND - Axillary Lymph Node \\ Dissection ; \\ BCS - Breast Conserving Surgery; \\ DCIS - Ductal Carcinoma In Situ; \\ EBC - Early Breast Cancer; \\ EIC - Extensive Intraductal Component; \\ IBTR - Ipsilateral Breast Tumor \\ Recurrence; \\ LDFS - Local Disease Free Survival; \\ OAS - Overall Survival; \\ RT - radiotherapy; \\ SPSS - Statistical Package for Social \\ Science;
}

Received: 13.02 .2018

Accepted: 23.03.2018

\section{Rezumat}

Factorii prognostici de eșec ai tratamentului pentru cancerul de sân incipient după operația de conservare a sânului

Introducere: Cancerul de sân este cel mai frecvent tip de cancer la femeile din țările occidentale dezvoltate şi devine şi mai semnificativ în multe țări în curs de dezvoltare. Chirurgia de conservare a sânilor a devenit standardul de aur pentru pacienții cu cancer de sân (stadiul I, II) cu cancer de sân timpuriu, cu o selecție adecvată a pacienților. Factori de risc importanți pentru eşecul tratamentului, includ starea marginilor de rezecție, vârsta, multicentricitatea tumorii şi utilizarea radioterapiei şi a terapiei hormonale adjuvante.

Scopul: Stabilirea variabilelor de prognostic pentru recidiva tumorilor mamare ipsilaterale în cancer de sân incipient după chirurgia conservatoare de sân şi rata de supraviețuire.

Materiale şi metodă: Am analizat 100 de paciente cu cancer de sân incipient care au suferit chirurgie de conservare a sânilor. Datele au fost analizate pentru eşecul tratamentului; analiza a fost efectuată prin test Chi-pătrat $\left(\chi^{2}\right)$, regresie multivariată Cox şi Kaplan Maier pentru analiza supraviețuirii.

Rezultate: 100 de pacienți au suferit chirurgie de conservare a sânilor pentru cancer de sân incipient. Au fost $75 \%$ dintre pacienții cu vârsta peste 40 de ani. Tumorile T2 au fost observate la $87 \%$ dintre pacienți şi la 53\% dintre pacienți au fost implicați noduli. Modelul de recurență a fost de $14 \%$; Pe analiza multivariată, gradul şi marja tumorilor au fost corelate cu supraviețuirea locală fără boală. Supraviețuirea fără boală locală la 3 ani şi supraviețuirea globală a fost de $86 \%$ şi, respectiv, $97 \%$. 
Concluzie: Chirurgia conservatoare a sânilor este o chirurgie acceptată pentru cancerul de sân timpuriu, cu un rezultat bun. Gradul şi marja tumorilor au fost corelate cu supraviețuirea locală fără boală.

Cuvinte cheie: cancer de sân în stadiu incipient, chirurgie conservatoare a sânilor, recidivă a tumorii mamare ipsilaterale

\begin{abstract}
Introduction: Breast cancer is the most common cancer in women in developed Western countries and is becoming even more significant in many developing countries. Breast conserving surgery (BCS) has become the gold standard for patients with early breast cancer (EBC) (Stage I, II) with an appropriate patient selection. Important risk factors for treatment failure, include margin status, age, tumour multicentricity and use of radiotherapy and adjuvant hormone therapy. Aim: To establish the prognostic variables for ipsilateral breast tumour recurrence (IBTR) in EBC after BCS and the survival rate.

Materials and Methods: We analyzed 100 patients with EBC who underwent BCS. Data were analyzed for treatment failure, an analysis was performed by Chi-square $\left(\chi^{2}\right)$ test, Cox multivariate regression and Kaplan Maier for survival analysis.

Results: 100 female patients underwent BCS for EBC. There were $75 \%$ of patients above 40 years old. T2 tumours were observed in $87 \%$ of patients and $53 \%$ patients had nodal involvement. There was a pattern of recurrence of 14\%; Using the multivariate analysis tumour grade and margin were correlated to local disease free survival. The 3 years local disease free survival and overall survival was of $86 \%$ and $97 \%$ respectively.

Conclusion: Breast conservative surgery is a highly accepted surgery for early breast cancer with good result. Tumour grade and margin were correlated to local disease free survival.
\end{abstract}

Key words: early breast cancer, breast conserving surgery, ipsilateral breast tumour recurrence

\section{Introduction}

Breast cancer is the most common cancer in women in developed Western countries and is becoming even more significant in many developing countries (1).

The results after breast conservative surgery and postoperative radiotherapy were very similar to those after mastectomy, breast conserving therapy becomes the treatment of choice for early breast cancer and no significant difference in long term survival has been observed (2).

Although breast conserving surgery has become the gold standard for patients with early breast cancer, mastectomy remains an option and it is necessary for at least $20 \%$ of the women with multicentric tumours, widespread ductal carcinoma in situ (DCIS), and large or recurrent tumours (3).

Appropriate patient selection is critical to the success of the BCS and it is an attempt to balance an acceptable low rate of local recurrence in the breast with good cosmetic outcome (4).

A complete history and physical examination bilateral mammography and ultrasound for breast and axilla tissue biopsy and patient desire, all play roles in patients selection and determine which surgery is best for each individual patient

Generally, recurrence is defined as the appearance of any new breast tumour, invasive or in situ, in the ipsilateral residual breast, in the overlying skin or in the ipsilateral axilla (5).

Risk factors for patients treated with 
conservative therapy, including high histologic grade, extensive intraductal component (EIC), tumour necrosis, oestrogen receptor negativity, anatomic tumour size, age younger than 40 years, and vascular invasion. Beyond established risk factors, genetic testing allows the identification of high-risk patients (BRCA mutation carriers) who may benefit from bilateral mastectomy rather than BCS. Human genetic variation and DNA methylation may be relevant for local failures assessment (6).

\section{Material and Methods}

Out of 112 female patients diagnosed with early breast cancer who were admitted to $\mathrm{Al}^{-}$ Amal Oncology Center, Taiz, Yemen, between June 2014 and May 2017, 100 patients were eligible for inclusion, 12 patients were excluded based on the presence of synochronouse/ metachronous contralateral breast carcinoma and on the presence of multicentric and multifocal breast cancer. The median follow up period was of 22 months.

In our research, the assessment was based on the clinical examination, bilateral mammography and ultrasound for breast and axilla (with BIRAD category), tissue biopsy and metastatic work up to exclude metastasis.

Patients underwent BCS which was defined as the surgical removal of the tumour with staging axillary lymph node dissection and postoperative radiation therapy The standard dose of radiotherapy (RT) given was of 5000 cGy administrated to the whole breast over a five week period divided into 25 daily sessions of radiotherapy, the standard boost of radiation was a further 1000 cGy given over 5 days.

\section{Axillary Lymph Node Dissection}

Underwent for level I and level II. Level III was taken only if it was involved intraoperative.

No $=$ No regional lymph node metastasis is histologically present.

$\mathrm{N} 1=$ Metastases in 1 to 3 axillary lymph nodes.

$\mathrm{N} 2=$ Metastases in four to nine axillary lymph nodes.
In our study a safety margin more than or equal to $1 \mathrm{~cm}$ called negative margin, positive margin is defined by the presence of tumour cells immediately at the resection edge (at an inked margin) and the close margin defined as cancer cells in-between the negative and the positive margin (not involving the resection edge and less than $1 \mathrm{~cm}$ ).

The local recurrence is defined by tumour recurrence in the ipsilateral breast. The regional recurrence happens when there is a nodal recurrence in the ipsilateral axillary or in the internal mammary lymph nodes. Loco regional recurrence means the tumour recurrence in both the ipsilateral breast and lymph nodes.

Local disease free survival (LDFS) is defined from the time of surgery to the date of local recurrence/last follow up.

Overall survival (OAS) is defined from the time of surgery to the date of the last follow up/death of the patients.

The statistical analysis was performed using SPSS (statistical package for social science), version 22 . The $\mathrm{P}$ value was significant at 0.05 . The comparison between the study groups was performed using Chi-square $\left(\chi^{2}\right)$ test. Cox multi-variate regression was used to determine the preferential effect of important variables on LDFS and Kaplan Maier for survival analysis.

\section{Result}

The mean age at the time of diagnosis was 49 years (range, 26 - 75 years).

A total of 100 patients underwent BCS. Eighty seven patients (87\%) had T2 tumour, fifty three patients $(53 \%)$ had nodal involvement (N1-N2), seventy six patients $(76 \%)$ had well (G1) and moderate (G2) tumour grade, thirty three (33\%) patients had hormone receptors negative breast cancer, ninety (90\%) patients had negative margins as according to (Table 1).

A pattern of treatment failure of female patients with EBC who underwent BCS showed that the incidence of IBTR was of $14 \%$ (Fig. 1).

A total of 14 patients had a recurrence, 12 
Table 1. Clinicopathological characteristics of the primary tumour and lymph nodes in female patients with early breast cancer who underwent breast conserving surgery

\begin{tabular}{|c|c|c|}
\hline & Number $\mathrm{N}=100$ & Percent \% \\
\hline \multicolumn{3}{|l|}{$\overline{\mathrm{Age}}$} \\
\hline$\leq 40$ & 25 & $25 \%$ \\
\hline$>40$ & 75 & $75 \%$ \\
\hline \multicolumn{3}{|l|}{ Family history } \\
\hline Positive & 19 & $19 \%$ \\
\hline Negative & 69 & $69 \%$ \\
\hline Unknown & 12 & $12 \%$ \\
\hline \multicolumn{3}{|l|}{ Tumour size } \\
\hline $\mathrm{T1}$ & 13 & $13 \%$ \\
\hline T2 & 87 & $87 \%$ \\
\hline \multicolumn{3}{|l|}{ Lymph node groups } \\
\hline NO & 47 & $47 \%$ \\
\hline N1 & 22 & $22 \%$ \\
\hline N2 & 31 & $31 \%$ \\
\hline \multicolumn{3}{|l|}{ Histology } \\
\hline Infiltrating ductal & 72 & $72 \%$ \\
\hline Infiltrating lobular & 19 & $19 \%$ \\
\hline Others & 9 & $9 \%$ \\
\hline \multicolumn{3}{|l|}{ Grade } \\
\hline Well $=\mathrm{G} 1$ & 11 & $11 \%$ \\
\hline Mod $=\mathrm{G} 2$ & 65 & $65 \%$ \\
\hline Poor $=\mathrm{G} 3$ & 24 & $24 \%$ \\
\hline \multicolumn{3}{|l|}{ Safety Margin Statues } \\
\hline Positive & 4 & $4 \%$ \\
\hline Negative & 90 & $90 \%$ \\
\hline Close & 6 & $6 \%$ \\
\hline \multicolumn{3}{|l|}{ EIC } \\
\hline Present & 13 & $13 \%$ \\
\hline Not present & 87 & $87 \%$ \\
\hline \multicolumn{3}{|l|}{ LVI } \\
\hline Positive & 16 & $16 \%$ \\
\hline Negative & 84 & $84 \%$ \\
\hline \multicolumn{3}{|l|}{ ER and PR status } \\
\hline Positive & 67 & $67 \%$ \\
\hline Negative & 33 & $33 \%$ \\
\hline \multicolumn{3}{|l|}{$\begin{array}{l}\text { Adjuvant systemic treatment } \\
\text { to radiotherapy }\end{array}$} \\
\hline Chemotherapy & 28 & $28 \%$ \\
\hline Hormonal & 5 & $5 \%$ \\
\hline Chemotherapy + hormonal & 59 & $59 \%$ \\
\hline None & 8 & $8 \%$ \\
\hline
\end{tabular}

ER: oestrogen receptors PR progesterone receptors

LVI: Lymphatic vascular invasion; EIC: Extensive intraductal component.

patients $(85.7 \%)$ had local recurrence, 1 patients had regional recurrence $(7.1 \%), 1$ patients with locoregional recurrence (7.1\%) (Table 2).

The incidence of IBTR is of $57.1 \%$ (8 patients) in six months and less, 7.1\% (1 patient) had a recurrence in the first year and $35.7 \%$ (5 patients) in the second year (Fig. 2).

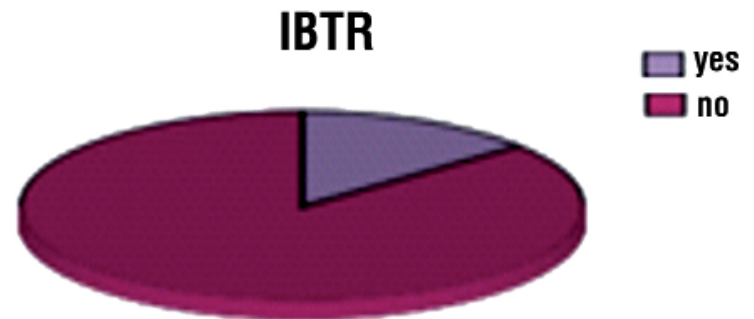

Figure 1. A pattern of treatment failure (recurrence)

Table 2. A pattern of observed recurrence in patients undergoing BCS and RT

\begin{tabular}{lcc}
\hline & $\begin{array}{c}\text { Number } \\
(\mathbf{N}=14)\end{array}$ & $\begin{array}{c}\text { Percentage } \\
\%\end{array}$ \\
\hline IBTR & & \\
\hline - Local recurrence & 12 & $85.7 \%$ \\
- Regional recurrence & 1 & $7.1 \%$ \\
- Locoregional recurrence & 1 & $7.1 \%$ \\
\hline Site of recurrence & & \\
\hdashline - At the operative bed or & & \\
$\quad$ within 3 cm from the incision & 13 & $92.9 \%$ \\
- Others & 1 & 7.1 \\
\hline IBTR ipsilateral tumour recurrence & & \\
\end{tabular}

The Pearson's chi-square test for independence between the IBTR and different categorical variables showed that, EIC, hormone receptors

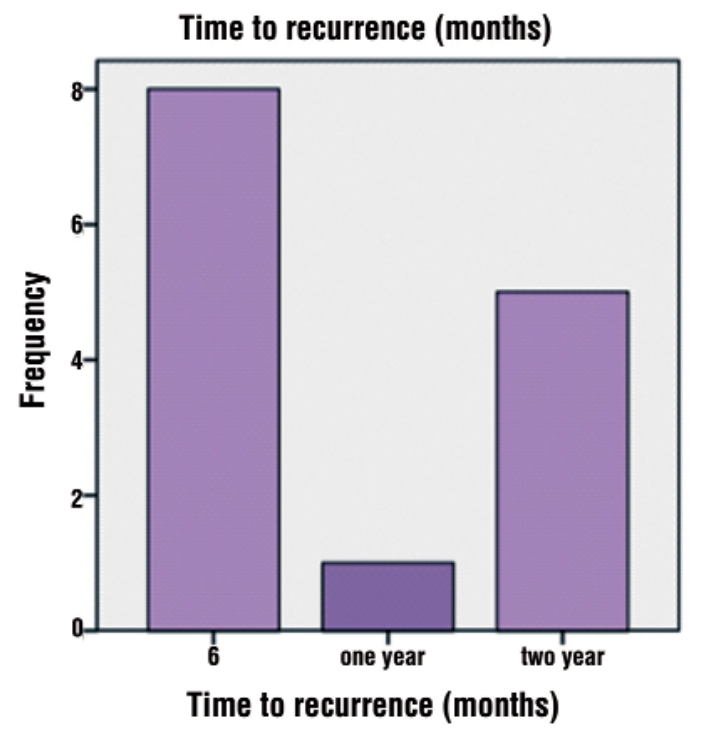

Figure 2. Time period to recurrence of 14 female patients with EBC (early breast cancer) who underwent BCS (breast conserving surgery) 
Table 3. Comparisons of categorical variables among groups were evaluated using Chi-square test for categorical variables

\begin{tabular}{cccc}
\hline & & Chi-Square Tests & \\
\hline & & df & P value \\
\hline & Age & 1 & 0.318 \\
\hline Progression & Tumor size & 1 & 0.312 \\
\hline & lymph node & 2 & 0.000 \\
\hline Histological type & 2 & 0.353 \\
\hline Grade & 2 & 0.001 \\
\hline LVI & Margin & 1 & 0.009 \\
\hline & ElC & 2 & 0.000 \\
\hline & Hormones receptors & 1 & 0.003 \\
\hline & Adjuvant therapy & 1 & 0.003 \\
\hline
\end{tabular}

df: Degree of freedom; LVI: Lymphatic vascular invasion; EIC: Extensiveintraductal component

status, histological grade, margins status, lymph node, LVI and adjuvant therapy were significantly associated with IBTR with P value (0.003 - 0.003 $0.001-0.000-0.000-0.009-0.001$ respectively) and there's no significant for IBTR and age, tumour size, histological type with $\mathrm{P}$ value ( .318 - 0.312- 0.353 respectively) (Table 3).

On multivariate analysis only tumour grade and margin were correlated to LDFS (Table 4).

The three year local disease free survival is of $86 \%$ (Fig. 3) and the three year overall survival is of $97 \%$ (Fig. 4).

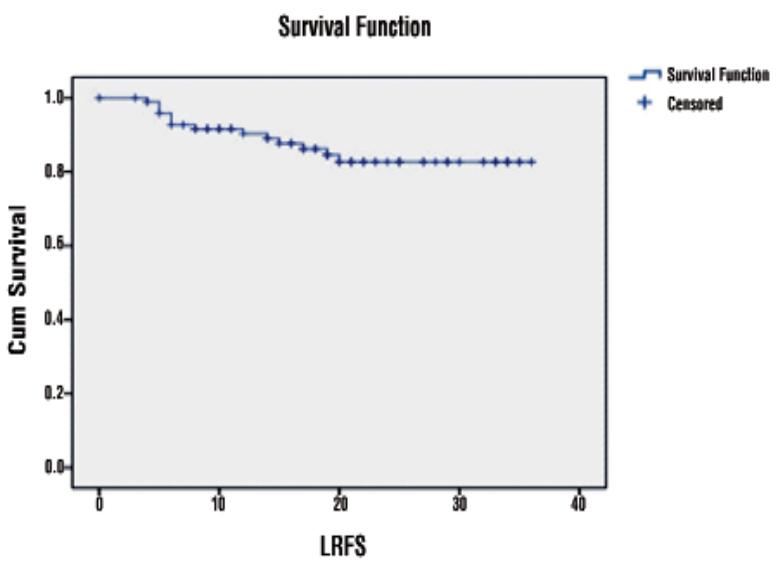

Figure 3. The Kaplan Meier curve for local disease free survival in breast cancer cases

Table 4. Factors influencing local disease free survival Results of Multivariate on Cox proportional hazards model analysis

\begin{tabular}{lcccc}
\hline & p value & HR & \multicolumn{2}{c}{$\mathbf{9 5 . 0 \%}$ Cl for HR } \\
\hline Age & & & Lower & Upper \\
\hline Family history & 0.137 & 0.195 & 0.023 & 1.681 \\
\hline Tumour Size & 0.130 & 0.100 & 0.005 & 1.969 \\
\hline Lymph Node & 0.935 & 0.913 & 0.102 & 8.199 \\
\hline Histological Type & 0.237 & 16.645 & 0.157 & $1,767.10$ \\
\hline Grade & 0.855 & 0.716 & 0.020 & 25.637 \\
\hline LVI & 0.009 & 138.38 & 3.439 & $5,567.72$ \\
\hline Margin & 0.537 & 2.514 & 0.135 & 46.825 \\
\hline EIC & 0.004 & 492.544 & 7.530 & $32,216.48$ \\
\hline Hormone receptors & 0.046 & 40.893 & 1.073 & $1,558.05$ \\
\hline Adjuvant therapy & 0.901 & 0.000 & 0.000 & $4.16 \mathrm{E}+98$ \\
\hline
\end{tabular}

HR: hazard ratio; Cl: confidence interval; LVI: Iymphatic vascular invasion; EIC: extensiveintraductal component. 


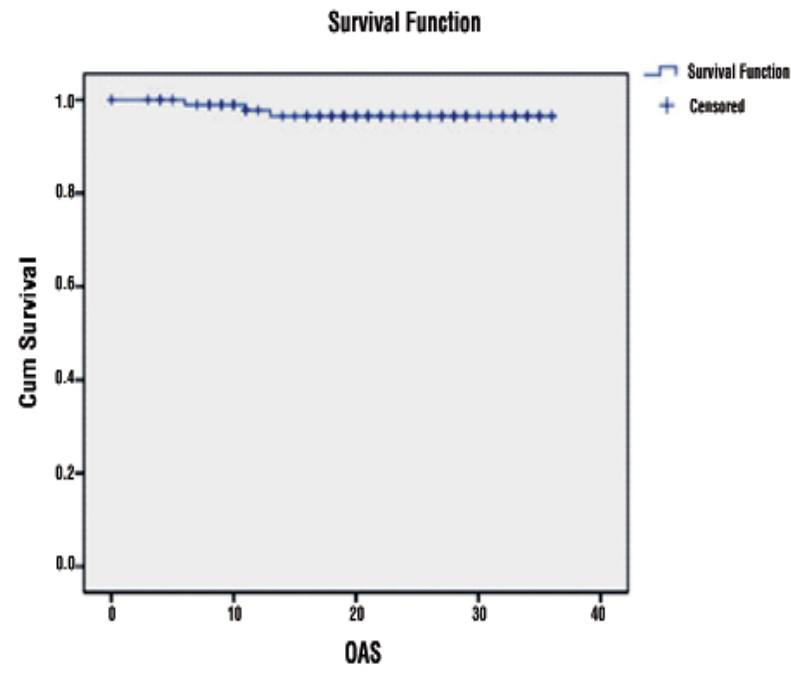

Figure 4. The Kaplan Meier curve for overall survival rate in breast cancer cases

\section{Discussion}

The risk of local recurrence in the breast after breast conserving surgery is between $1 \%$ and $2 \%$ per year and it is relatively constant over time, with an overall ten year risk of $10-20 \%$. However, the reported incidences do vary considerably between series, due to differences in patient's selection, the extent of surgery and usage of postoperative adjuvant radiotherapy and systemic treatment. Although the risk of local recurrence after mastectomy has generally been considered to be much lower than after breast conserving surgery, most of the randomized comparative studies have not demonstrated any significant difference in this respect $(7,8)$. According to our study, approximately $14 \%$ of women had IBTR after breast conserving surgery with a peak incidence of $57.1 \%$ in six months, $7.1 \%$ had a recurrence in one year and $35.7 \%$ in the second year. NSABP B 06 trial reported nearly 5\% rate of locoregional recurrence in patients undergoing breast conservative surgery at 5 years (9). The EORTC trial demonstrated $11.8 \%$ rate of locoregional recurrence at 5 years (10).

Although mammography is a dominant screening tool, the importance of Clinical breast examination should not be over looked. A significant number of cancers would have been missed if clinical breast examination (CBE) had not been performed. In contrast with cancers detected by mammography alone, those detected by clinical breast examination had more aggressive features. Clinical breast examination (CBE) is a low-cost assessment that could improve the detection of breast cancer and could prompt breast ultrasonography in the case of a negative mammogram (11).

Local recurrence of a tumour after breast conserving therapy often occurs as a single nodule with or without axillary node recurrence. The usual sites of local recurrence are in the same quadrant as the primary tumour $(48 \%)$, in another quadrant (41\%), or both (11\%) (12). In our study $92.9 \%$ had recurrence at the same operative bed or within $3 \mathrm{~cm}$ from the incision.

Tumour size wasn't correlated to any of the outcome results in this study, but in several studies clinical size of tumour more than $2 \mathrm{~cm}$ (T2) was associated with higher risk of IBTR (13).

In our study positive margins correlate with IBTR and local disease free survival on multivariate analysis. In 30 of 43 studies reviewed by Singletary, the local recurrence rate was increased in the cases that had persistent positive margin compared with negative margins. This effect appeared to be independent of the size of the margin (14). Authors found the 10-year local recurrence free survival rate for young women $(<40$ years) with positive margins to be significantly lower compared with negative margins $(34.6 \%$ vs. $84.4 \%$, respectively; $p=0.008$ ). The effect of positive margin status for invasive cancer is not only limited to local control, but also to distant metastasis and survival (15).

On ivariable analysis, the patients with close or positive margins, in combination with age $<$ 45 years, Grade III,LVI, and $\geq 4$ positive nodes, have a 5-year local recurrence (LR) $>10 \%$ despite whole breast plus boost radiotherapy. So these patients should be considered for more re-resection surgery (16).

In the present study the axillary lymph node- correlates to IBTR. Despite a strong 
association between axillary lymph node status and survival associated with local recurrence in breast conserving therapy, while present, is not as strong or as consistent, it may be due to the almost universal use of radiotherapy and adjuvant therapy in node positive patients (17).

Sentinel lymph node biopsy is a minimally invasive procedure which is an alternative to axillary lymph node dissection (ALND) in staging the axilla in patients with early invasive breast cancers and clinically negative node. It has the potential to improve the accuracy of axillary staging while reducing the number of unnecessary axillary dissection and decreasing morbidity. The safety of the sentinel lymph node biopsy was underscored by the NSABP B-32 trial which showed that overall survival (OS), disease free survival (DFS) and regional control (RC) were statistically equal between the sentinel lymph node and standard axillary node dissection when the node was negative (18).

Tumour grade and lymphovascular invasion were correlated to IBTR in this study. Voogd et al, stated that vascular invasion and to a lesser extent high histological grade, appeared to cause an increased risk of local recurrence irrespective of the primary treatment (19). Some series have also found an increased risk of breast recurrence in patients with high histological grade tumours compared with low grade tumours (20). In this study tumour grade also correlates with local disease free survival on multivariate analysis.

Breast cancer patients with estrogen receptor positive and/or progesterone receptor negative have lower risks of mortality, improved outcomes and associated with a longer survival time after their diagnosis (21).

The 3 years local disease free survival and overall survival were of $86 \%$ and $97 \%$ respectively, comparable to the result from another study with 10 years local disease free survival and overall survival of $88 \%$ and $70 \%$ respectively (22).

\section{Conclusion}

- Breast conservative surgery is a highly
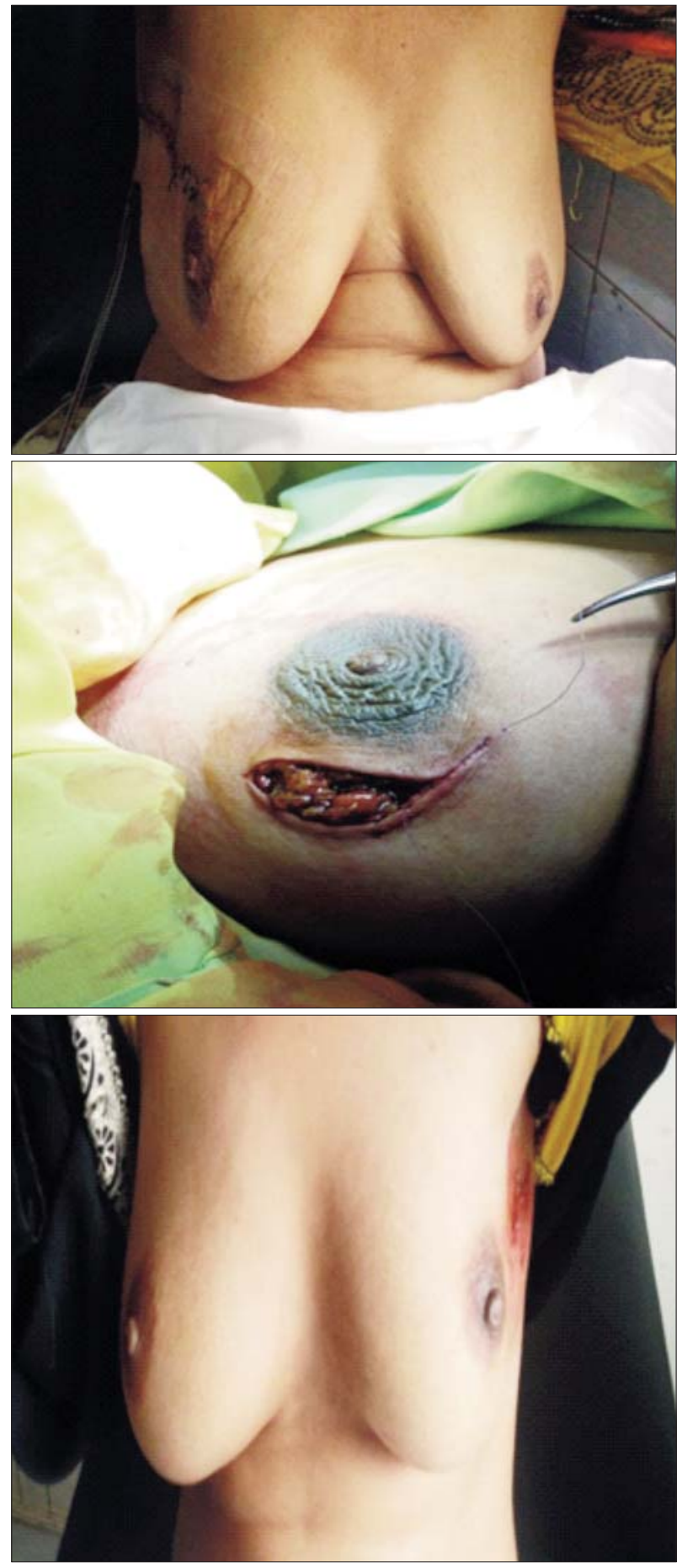

Figure 5. The result of breast conservative surgery

accepted surgery for early breast cancer with good result.

- Lymph node, hormone receptors, lymphovascular invasion and the adjuvant therapy are correlated to IBTR.

- Tumour grade and safety margin are 
correlated to IBTR and local disease free survival on multivariate analysis.

- The 3 years local disease free survival and overall survival was of $86 \%$ and $97 \%$ respectively.

\section{Conflict of Interests}

The authors declare no conflict of interests.

\section{References}

1. Shoma AM, Mohamed MH, Nouman N, Amin M, Ibrahim IM, Tobar SS, et al. Body image disturbance and surgical decision making in Egyptian post-menopausal breast cancer patients. World J Surg Oncol. 2009;7:66. doi: 10.1186/1477-7819-7-66.

2. Sharief MA, Mamoon N, Mushtaq S, Khadim MT, Jamal S. Steroid hormone receptors associated with prognostic markers in breast carcinoma in northern Pakistan. Journal of the College of Physicians and Surgeons Pakistan. 2010;20(3):181-5.

3. Petit JY, Veronesi U, Luini A, Orecchia R, Rey PC, Martella S, et al. When mastectomy becomes inevitable: the nipple-sparing approach. Breast. 2005;14(6):527-31. Epub 2005 0ct 12.

4. Morrow M, Strom EA, Bassett LW, Dershaw DD, Fowble B, Giuliano $A$, et al. Standard for breast conserving therapy in the management of invasive breast carcinoma. CA Cancer J Clin. 2002;52(5):277-300.

5. Fredriksson I, Liljegren G, Palm-Sjövall M, Arnesson LG, Emdin SO, Fornander T, et al. Risk factors for local recurrence after breastconserving surgery. Br J Surg. 2003; 90(9): 1093-102.

6. Ziogas D and Roukos DH. Genetics and personal genomics for personalized breast cancer surgery. Ann Surg Oncol. 2009; 16(7):1771-82. doi: 10.1245/s10434-009-0436-2. Epub 2009 Mar 26.

7. Fisher B, Redmond C, Poisson R, Margolese R, Wolmark N, Wickerham $\mathrm{L}$, et al. Eight-year result of a randomized clinical tria comparing total mastectomy and lumpectomy with or without irradiation in the treatment of breast cancer. N Engl J Med. 1989; 320(13):822-8. Erratum in N Engl J Med 1994;330(20):1467.

8. Voogd AC1, Nielsen M, Peterse JL, Blichert-Toft M, Bartelink H, Overgaard $\mathrm{M}$, et al. Differences in risk factors for local and distant recurrence after breast-conserving therapy or mastectomy for stage I and II breast cancer: pooled results of two large European randomized trials. J Clin Oncol. 2001;19(6):1688-97. Erratum in J Clin Oncol 2001; 19(9):2583.

9. Fisher B, Anderson S, Bryant J, Margolese RG, Deutsch M, Fisher $E R$, et al. Twenty-year follow-up of a randomized trial comparing total mastectomy, lumpectomy, and lumpectomy plus irradiation for the treatment of invasive breast cancer. N Engl J Med. 2002; 347(16):1233-41.

10. van Dongen JA, Voogd AC, Fentiman IS, Legrand C, Sylvester RJ,
Tong D, et al. Long-term results of a randomized trial comparing breast-conserving therapy with mastectomy: European Organization for Research and Treatment of Cancer 10801 trial. J Natl Cancer Inst. 2000;92(14):1143-50.

11. Provencher L, Hogue JC, Desbiens C, Poirier B, Poirier E, Boudreau D, et al. Is clinical breast examination important for breast cancer detection? Curr Oncol. 2016;23(4):e332-9. doi: 10.3747/c0.23.2881. Epub 2016 Aug 12.

12. Kim H, Kim EK, Kwak JY, Kim MJ, Choi SH, Park BW. Solitary drain-site recurrence after lumpectomy for breast cancer. Yonsei Med J. 2010;51(3):469-71. doi: 10.3349/ymj.2010.51.3.469.

13. Rouzier R, Extra JM, Carton M, Falcou MC, Vincent-Salomon A, Fourquet A, et al. Primary chemotherapy for operable breast cancer: incidence and prognostic significance of ipsilateral breast tumor recurrence after breast-conserving surgery. J Clin Oncol. 2001; 19(18):3828-35.

14. Singletary SE. Surgical margins in patients with early-stage breast cancer treated with breast conservation therapy. Am J Surg. 2002; 184(5):383-93.

15. Pleijhuis RG, Graafland M, de Vries J, Bart J, de Jong JS, van Dam GM. Obtaining adequate surgical margins in breast-conserving therapy for patients with early-stage breast cancer: current modalities and future directions. Ann Surg Oncol. 2009; 16(10):2717-30. doi: 10.1245/ s10434-009-0609-z. Epub 2009 Jul 17.

16. Lupe K, Truong PT, Alexander C, Lesperance M, Speers C, Tyldesley S. Subsets of women with close or positive margins after breastconserving surgery with high local recurrence risk despite breast plus boost radiotherapy. Int J Radiat Oncol Biol Phys. 2011; 81(4):e561-8. doi: 10.1016/j.jijrobp.2011.02.021. Epub 2011 Apr 20.

17. Mccready DR, Chapman JA, Hanna WM, Kahn HJ, Yap K, Fish EB, et al. Factors associated with local breast cancer recurrence after lumpectomy alone: postmenopausal patients. Ann Surg Oncol. 2000;7(8):562-7.

18. Chatterjee A, Serniak N, Czerniecki BJ. Sentinel lymph node biopsy in breast cancer: a work in progress. Cancer J. 2015;21(1):7-10. doi: 10.1097/PP0.0000000000000090.

19. Voogd AC, Nielsen M, Peterse JL, Blichert-Toft M, Bartelink H, Overgaard M, et al. Differences in risk factors for local and distant recurrence after breast-conserving therapy or mastectomy for stage I and II breast cancer: pooled results of two large European randomized trials. J Clin Oncol. 2001;19(6):1688-97. Erratum in J Clin Oncol 2001; 19(9):2583.

20. Mate TP, Carter D, Fischer DB, Hartman PV, McKhann C, Merino M, et al. A clinical and histopathological analysis of the results of conservative surgery and radiation therapy in Stage I and II breast cancer. Cancer. 1986;58(9):1995-2002.

21. Anderson WF, Chu KC, Chatterjee N, Brawley 0, Brinton LA. Tumour variants by hormone receptor expression in white patients with nodenegative breast cancer from the surveillance, epidemiology, and end result database. J Clin Oncol. 2001;19(1):18-27.

22. Bhatti $A B$, Jamshed $A$, Shah MA, Khan A. Breast conservative therapy in Pakistani women: Prognostic factors for locoregional recurrence and overall survival. J Cancer Res Ther. 2015;11(2): 300-4. doi: 10.4103/0973-1482.140828. 